\title{
The Developmental Nature of the Victim-Offender Overlap
}

\author{
Amber L. Beckley ${ }^{1,2}$ - Avshalom Caspi ${ }^{1,3,4,5}$. \\ Louise Arseneault ${ }^{5}$ • J. C. Barnes ${ }^{6}$. \\ Helen L. Fisher ${ }^{5}$ - Honalee Harrington ${ }^{1}$. \\ Renate Houts $^{1}$ - Nick Morgan ${ }^{7}$. \\ Candice L. Odgers ${ }^{8}$. Jasmin Wertz ${ }^{1}$. \\ Terrie E. Moffitt ${ }^{1,3,4,5}$
}

Received: 17 March 2017 /Revised: 2 September 2017 /Accepted: 21 September 2017 /

Published online: 9 October 2017

(C) The Author(s) 2017, corrected publication November/2017. This article is an open access publication

\begin{abstract}
Purpose It is well-established that victims and offenders are often the same people, a phenomenon known as the victim-offender overlap, but the developmental nature of this overlap remains uncertain. In this study, we drew from a developmental theoretical framework to test effects of genetics, individual characteristics, and routine-activitybased risks. Drawing from developmental literature, we additionally tested the effect of an accumulation of adverse childhood experiences (ACEs).

Methods Data came from the Environmental Risk (E-Risk) Study, a representative UK birth cohort of 2232 twins born in 1994-1995 and followed to age 18 (with $93 \%$
\end{abstract}

Electronic supplementary material The online version of this article (https://doi.org/10.1007/s40865-0170068-3) contains supplementary material, which is available to authorized users.

Amber L. Beckley

amber.beckley@duke.edu

1 Department of Psychology and Neuroscience, Duke University, Durham, NC, USA

2 Demography Unit, Stockholm University, Stockholm, Sweden

3 Department of Psychiatry and Behavioral Sciences, Duke University, Durham, NC, USA

4 Centre for Genomic and Computational Biology, Duke University, Durham, NC, USA

5 MRC Social, Genetic \& Developmental Psychiatry Centre, Institute of Psychiatry, Psychology \& Neuroscience, King's College London, London, UK

6 School of Criminal Justice, University of Cincinnati, Cincinnati, OH, USA

7 Home Office Science, London, UK

8 Center for Child and Family Policy and the Sanford School of Public Policy, Duke University, Durham, NC, USA 
retention). Crime victimization and offending were assessed through self-reports at age 18 (but findings replicated using crime records). We used the classical twin study method to decompose variance in the victim-offender overlap into genetic and environmental components. We used logistic regression to test the effects of childhood risk factors.

Results In contrast to past twin studies, we found that environment (as well as genes) contributed to the victim-offender overlap. Our logistic regression results showed that childhood low self-control and childhood antisocial behavior nearly doubled the odds of becoming a victim-offender, compared to a victim-only or an offender-only. Each additional ACE increased the odds of becoming a victim-offender, compared to a victim-only or an offender-only, by approximately $12 \%$, pointing to the importance of cumulative childhood adversity.

Conclusions This study showed that the victim-offender overlap is, at least partially, developmental in nature and predictable from personal childhood characteristics and an accumulation of many adverse childhood experiences.

Keywords Victim-offender overlap · Developmental criminology · Adverse childhood experiences $\cdot$ Low selfcontrol

\section{Introduction}

The connection between crime victimization and offending, known as the victimoffender overlap, is a well-established "fact" in criminology [63]. Victimization and offending both peak in adolescence and have been shown to be significantly associated with one another regardless of the type of data used, or the type of offending and victimization analyzed [66]. The significant overlap between victimization and offending appears across different countries and ethnic groups and applies to both violent and non-violent crime $[62,72,92,93,101]$. Studies report that upwards of half of victims are offenders and vice-versa [63] and the size of the correlation between victimization and offending is large, relative to other effect sizes found in criminology [61, 94, 95] (e.g., $r=0.30-0.50$ [6]; $r=0.29$ [39]; $r=0.24$ [108]; $r=0.42$ [114]). Victimization and offending are so intertwined that, some have argued, the understanding of one necessitates consideration of the other [66].

There has, however, been a modest amount of effort devoted to understanding the developmental etiology of the overlap despite a call for the investigation into biological mechanisms behind the overlap [66], and despite evidence that childhood risk factors, such as low self-control, are common risks for both adolescent victimization and offending [94, 95]. The lack of studies on the developmental nature of the overlap appears to be rooted in a lack of data. There are only two published studies on the genetic underpinnings of the victim-offender overlap [6, 118]. Additionally, we are not aware of any other published study that has examined the link between childhood risk factors, as assessed during the first decade of life, and later victim-offender overlap, and datasets for doing this work are few. Childhood risk factors have been identified in studies of offending, and some of the same childhood risk factors have been identified in separate studies of victimization, but few studies can test which risk factors differentiate victim-offenders from comparison groups of pure offenders and pure victims. 
Our study adds to the body of research on the victim-offender overlap by addressing its developmental nature using the Environmental Risk (E-Risk) Study, a populationrepresentative prospective longitudinal study of a 1994-1995 birth cohort of 1116 twin pairs from England and Wales, in which victimization and offending were assessed at age 18 years. Our twin design enabled us to add to the extant research by taking a behavioral genetic approach to the study of the victim-offender overlap. We additionally included prospective early- and middle-childhood risks measured up to age 12. Our study provides new evidence on the effect of cumulative adverse childhood experiences (as opposed to any individual experience) on the victim-offender overlap using both variable- and person-centered approaches. Our multimethod approach goes beyond past studies, which have typically relied on single measurement methods (e.g., selfreport only) and a single analytical approach. We begin by briefly reviewing the literature on the victim-offender overlap. For a complete review of theory and past research on the overlap, we direct readers to three excellent reviews: Jennings et al. [63], Lauritsen and Laub [66], and Schreck and Stewart [111].

\section{Past Victim-Offender Overlap Research from a Developmental Perspective}

Three general streams of research form the basis of knowledge on the victim-offender overlap. The first stream of research concerns the influence of genetics on the victimoffender overlap. Children may be genetically predisposed to develop certain characteristics (e.g., low self-control, substance use) which are related to both victimization and offending. Genetically influenced characteristics may also evoke an environment conducive to the victim-offender overlap. For example, genes influence poor educational attainment $[11,83]$, which may, in turn, create an environment conducive to becoming a victim-offender. To date, two twin studies have reported substantial genetic influence on the victim-offender overlap $[6,118]$. In addition, research on bullying has pointed to the importance of genetic factors in explaining the overlap between bullying perpetration and bullying victimization in children [5]. Although behavioral genetic methods have been a source of controversy in criminology $[8,18,77]$, these provocative findings merit further replication efforts.

A second stream of victim-offender overlap research focuses on individual heterogeneity. This research flags individual-level characteristics as the key to the victimoffender overlap $[12,13,66]$. In line with the general theory of crime [50], it has been argued that the victim-offender overlap is due to low self-control [111]. Many studies, however, have measured low self-control concurrently with victimization and offending, leaving open the possibility of reverse causation, in which being a victimoffender diminishes self-control.

The dual taxonomy of antisocial behavior [75] also identifies individual-level characteristics that may be linked to the victim-offender overlap. Low cognitive ability, shown to be distinct from low self-control [76], may impede the decision-making process where risks and rewards are evaluated, thereby increasing the risk of offending. Research has consistently linked low cognitive ability with offending [54] and has implied that low cognitive ability may also increase the risk of victimization $[4,10$, $106,107]$. The dual taxonomy also identifies early puberty as a risk for the victim- 
offender overlap. Youths experiencing early puberty may have a prolonged maturity gap in which they attempt to mimic "adult" behaviors, which manifest as crime, but which also expose youths to the risk of victimization [75]. Young adolescents experiencing early puberty may be at increased risk of crime victimization through unstructured socialization with older-aged peers [58] and by facing new developmental pressures before completing age-appropriate developmental tasks [88, 115]. However, empirical support for early puberty as a risk for the overlap, like low cognitive ability, comes from separate studies on offending and victimization $[20,25,32,42,51,53,57$, $58,109,121]$.

The third stream of victim-offender overlap research is rooted in routine activity theory. Despite the explicit situational focus of routine activity theory [86], the constructs identified by the routine activity framework can also be integrated into a developmental perspective on crime. Routine activity theory states that crime results from the non-random convergence of likely offenders, suitable targets, and a lack of capable guardians [23, 48, 59]. The non-random convergence of these elements is based on the similar lifestyles of potential offenders/targets. The theory flags a number of constructs which have been shown to be relevant for victimization and offending separately and/or the victim-offender overlap. In this research, we focus on: delinquency $[1,69,106,122]$, substance use and substance using peers [37, 41, 49, 67, 112], low parental monitoring [15, 21, 85, 86], and neighborhood crime and victimization [24]. Indeed, research shows that adolescent delinquency and adolescent substance use arise from developmental processes beginning as early as the neonatal stage and share notable behavioral predictors during childhood [55]; [70]; [71]. Low parental monitoring and neighborhood crime and victimization are not only factors that create situations conducive to crime, but they are also developmental risk factors that shape the attitudes and future behavior of children [26, 33, 47, 87].

\section{Understanding the Developmental Nature of the Victim-Offender Overlap Through Cumulative ACEs}

Adverse childhood experiences (ACEs) are potentially preventable childhood risk factors for poor adult health and social problems [40]. The original ACEs list, recommended by the U.S. Center for Disease Control and Prevention, includes physical abuse, sexual abuse, emotional abuse, emotional neglect, physical neglect, domestic violence exposure, criminality in the household, household substance abuse, mental illness in household, and parental separation or divorce [2]. The hypothesized association between ACEs and the victim-offender overlap is suggested by Widom's research on abused and/or neglected children which has shown, albeit in separate studies, that maltreated children are likely to grow up to be both crime victims and offenders [73, $74,104,119,120]$. Other studies in criminology have also documented the relationship between ACEs and the risk of later victimization or later offending, although they have not explicitly tested the contribution of these to the victim-offender overlap, per se [9, 17, 30, 38, 56, 60, 65, 68, 113].

Criminological theories flag a number of additional experiences that may be relevant to explaining the victim-offender overlap and that can be added as adjuncts to the conventional ACEs. The idea of "expanding" ACEs was solidified by the Philadelphia 
ACEs Survey [28]. From routine activity theory and the results of the Philadelphia ACEs survey, we identified 10 additional adversities that could be found in the E-Risk Study dataset and that are potentially important to the victim-offender overlap: experiencing bullying, living in foster care, low childhood socioeconomic status, peer substance abuse, low parental monitoring (as evaluated by parents), low parental monitoring (as evaluated by children), participant-perceived unsafe neighborhood, high neighbor crime victimization measured via neighbor survey, neighborhood rated as unsafe through systematic social observation, and high-crime neighborhood measured through official police records.

In line with developmental theories of risk, the effect of ACEs is cumulative in nature [40]. Cumulative effects have not yet been considered in victim-offender overlap research. ${ }^{1}$ Indeed, past overlap research has controlled for many factors simultaneously and has generally found weak effects of presumed risk factors. Including many risk factors separately in a single statistical model yields estimates for each individual risk while controlling for the other risks, but does not account for the effect that many accumulated risks may have on the individual as does a summed count measure of risks. Counting risk factors cumulatively is a useful way to reduce measurement error, increase validity, and simultaneously account for correlated risk factors [35, 36]. Studies have shown that even when each individual risk experience has a weak or nil effect, the accumulation of multiple risk experiences has greater detrimental developmental effects, i.e., the sum is greater than its parts $[35,36]$.

There are a few ways to understand how an accumulation of ACEs may influence the victim-offender overlap. First, accumulated ACEs are likely to lead children to have low-quality, or insecure, attachment to their caregivers $[19,27]$. Children subsequently model poor parent-child relationships in other interpersonal relationships throughout life [22]. There is evidence that children with positive perceptions of their family climate are at a lower risk of crime victimization [110] and that poor caregiver attachment can result in children who are inhibited and anxious or hostile and aggressive [14], potential risks for becoming a victimoffender. Second, an accumulation of many ACEs may teach children that violence perpetration and violent victimization are normal, expectable, and even acceptable. Third, when accumulated ACEs include multiple forms of childhood maltreatment/neglect, low self-control may ensue, and thereby increase the risk of adolescent victimization and offending [111].

Fourth, the accumulation of many ACEs in a life may lead to pathophysiologic consequences likely to increase the risk of offending [3, 29]. Exposure to chronic stress, in the form of multiple ACEs, while the brain is developing may lead to structural and functional abnormalities in regions of the brain (the prefrontal cortex, the amygdala, and the hippocampus) linked to crime and antisocial behavior [100]. Cortisol levels, also affected by chronic stress, may interact with testosterone to increase antisocial behavior [31, 46, 79]. Fifth, some ACEs are known to be under genetic influence (e.g., familial substance abuse or mental illness, family violence), which implies that the statistical prediction from ACEs to

\footnotetext{
${ }^{1}$ The effect of cumulative adversities that we discuss and measure differs from the process of cumulative disadvantage described in life-course theory [105], which describes how, through the process of labeling, young offenders experience subsequent life failures, leading to adult offending.
} 
the later victim/offender overlap could, in part, operate through the aforementioned genetic pathways [91].

\section{The Present Study}

In this study, we analyzed data on 18-year-old twin pairs to test explanations of the overlap between victimization and offending behavior. We first established that the overlap between victim status and offender status exists in the present cohort. We then exploited the twin design to test for genetic and environmental contributions to the victim-offender overlap. We further exploited the study's prospective longitudinal design to test hypotheses that childhood risk factors would predict the victimoffender overlap. We drew from theories of individual heterogeneity and routine activity theory to test hypotheses that childhood personal risk factors predicted the victim-offender overlap. We additionally created a count reflecting each child's accumulation of conventional ACEs and expanded ACEs, which included experiential factors (i.e., factors external to the child) flagged by routine activity theories, to test their ability to predict the victim-offender overlap.

Using variable-centered and person-centered approaches, we tested the hypotheses that

H1: Both genes and environment contribute to the victim-offender overlap.

$\mathrm{H} 2$ : Childhood personal risk factors positively contribute to the victim-offender overlap.

H3: The accumulation of adverse childhood experiences (ACEs) positively contributes to the victim-offender overlap.

\section{Data}

\section{Participants}

Participants were members of the Environmental Risk (E-Risk) Longitudinal Twin Study, which tracks the development of a birth cohort of 2232 British children. The sample was drawn from a larger birth register of twins born in England and Wales in 1994-1995 [117]. Full details about the sample are reported elsewhere [78]. Briefly, the E-Risk sample was constructed in 1999-2000, when 1116 families (93\% of those eligible) with same-sex 5-year-old twins participated in home-visit assessments. Follow-up home visits were conducted when the children were aged 7 (98\% participation), 10 (96\% participation), 12 (96\% participation), and, in 2012-2014, 18 years (93\% participation). There were no differences between those who did and did not take part at age 18 in terms of socioeconomic status (SES) assessed when the cohort was initially defined $\left(\chi^{2}=0.86\right.$, $p=.65)$, age 5 IQ scores $(t=0.98, p=.33)$, or age 5 internalizing or externalizing behavior problems $(t=0.40, p=.69$ and $t=0.41, p=.68$, respectively). The sample includes $55 \%$ monozygotic and $45 \%$ dizygotic twin pairs; sex is evenly distributed within zygosity (49\% male). We have, in our analyses of the E-Risk data, adjusted the standard errors and confidence intervals for clustering of twins within families. 
Families were recruited to represent the UK population of families with newborns in the 1990s, on the basis of residential location throughout England and Wales, and mother's age. Teenaged mothers with twins were overselected to replace high-risk families who were selectively lost to the register through nonresponse. Older mothers having twins via assisted reproduction were underselected to avoid an excess of well-educated older mothers. These strategies ensured that the study sample represents the full range of socioeconomic conditions in Great Britain, as reflected in the families' distribution on a neighborhood-level socioeconomic index (ACORN [A Classification of Residential Neighborhoods], developed by CACI Inc. for commercial use) [82]: $25.6 \%$ of E-Risk families live in "wealthy achiever" neighborhoods compared to $25.3 \%$ nationwide, 5.3 vs. $11.6 \%$ live in "urban prosperity" neighborhoods, 29.6 vs. $26.9 \%$ live in "comfortably off" neighborhoods, 13.4 vs. $13.9 \%$ live in "moderate means" neighborhoods, and 26.1 vs. $20.7 \%$ live in "hard-pressed" neighborhoods. E-Risk underrepresents "Urban Prosperity" because such households are significantly more likely to be childless. Since study participants live all over England and Wales, there was no geographic clustering (beyond twins within families) of individuals within neighborhood locations.

\section{Victimization at Age 18 Years}

To assess victim status, participants were interviewed face-to-face at age 18 years about their crime victimization experiences between ages 12 and 18 years, which are the years in secondary school in the UK (a meaningful reporting period for the respondents). Face-to-face interviews were conducted to allow the clinical interviewer to administer probes and also to respond if a twin became distressed. Standardized interviews used the Juvenile Victimization Questionnaire 2nd revision (JVQ-R2) [44, 52], adapted as a clinical interview [45]. The JVQ-R2 was developed at the University of New Hampshire Crimes Against Children Research Center, has good psychometric properties [43], has been used extensively in nationwide US surveys (including the National Survey of Children's Exposure to Violence), and was used in the UK National Society for the Prevention of Cruelty to Children (NSPCC) national survey [98, 99]. Study members were asked whether they had been a victim of a variety of types of physical assault (10 types), property crime (3 types), sexual assault (4 types), or internet/mobile phone harassment (3 types). ${ }^{2}$

Affirmative ("yes") responses to each of the 20 victimization questions were summed to create a victimization variety score. Forty-eight percent of Study members reported at least one type of victimization and, on average, Study members reported 1.52 different types of victimization each. E-Risk Study members' victimization was similar to that of lifetime victimization reported for the NSPCC sample [45]. See Tables S.1 and S.2 for descriptive statistics about victimization.

\footnotetext{
${ }^{2}$ Internet and mobile phone harassment are criminal offenses under UK law. Details can be found here: http://www.cps.gov.uk/legal/a_to_c/communications_sent_via_social_media/ and here: http://www.cps.gov. uk/legal/s_to_u/stalking_and_harassment/\#a05a
} 


\section{Offending at Age 18 years}

To assess offender status, participants completed a computer questionnaire at age 18 years which asked about their engagement in a variety of types of offending behaviors between ages 17 and 18 years. A computer questionnaire, as opposed to a face-to-face interview, was administered as distress was not expected and validity of reporting illegal behaviors by teens is enhanced by a computer format [103]. The respondent was able to read the short description of each crime on the screen, while also hearing it over headphones to eliminate any effects of poor reading skill. There were 20 questions about non-violent offenses such as theft, fraud, vandalism, breaking and entering, and selling drugs. There were 13 questions about violent offenses such as assault, robbery, making threats, and carrying a weapon.

Affirmative ("yes") responses to each of the 33 offending questions were summed to create an offending variety score. Fifty percent of Study members reported any type of offending and, on average, Study members reported 1.74 different types of offending each. See Table S.1 for descriptive statistics about offending.

\section{Personal Risk Factors Ages 5-12 Years}

We included the following childhood personal risk factors that have been theoretically linked to the victim-offender overlap: low self-control, low cognitive ability, early puberty, conduct disorder diagnosis, pre-teen delinquent behavior, and pre-teen substance use. These risk factors were measured during childhood up to age 12 years, preceding the measurement of both victimization and offending, providing stronger grounds for causal inference based on temporal order. Measurement details are provided in Table S.1.

\section{Accumulation of Adverse Childhood Experiences}

We measured ACEs in two categories. First, we measured conventional ACEs [40]: physical abuse, sexual abuse, emotional abuse and neglect, physical neglect, domestic violence exposure, parental antisocial behavior, family history of substance abuse, family history of mental health disorders, and parental separation or divorce. Second, from the results from the PHL ACEs survey and routine activity theory, we identified 10 adversities that we could test as part of the E-Risk Study: experiencing bullying, living in foster care, low childhood socioeconomic status, peer substance abuse, low parental monitoring (as evaluated by parents), low parental monitoring (as evaluated by children), participant-perceived unsafe neighborhood, high neighbor crime victimization measured via neighbor survey, neighborhood rated as unsafe through systematic social observation, and high-crime neighborhood measured through official police records. Sixteen ACEs were measured during childhood up to age 12 years; 3 neighborhood ACEs were measured between ages 13 and 17; measurement details are provided in Table S.1. The correlations between the items in our ACEs scale can be found in Table S.3.

We additionally created a summary scale of all risk factors. The summary scale of all risk factors added conventional ACEs, expanded ACEs, and personal risk factors. Study members were counted as having the personal risk factor if they were in the 
top quartile of low self-control, early puberty, childhood self-reported delinquency, and childhood substance use; in the bottom quartile of cognitive ability; met the diagnostic criteria for conduct disorder.

All analyses were carried out in R 3.3.1 [97] using the following packages: OpenMx $[16,80,96]$, ppcor [64], and compareGroups [116].

\section{Results}

Our preliminary analytic step was to verify that the victim-offender overlap existed in our data. Study members were about 1.5 times as likely to be victim-offenders (29\%) compared to victims-only (16\%) or offenders-only (20\%). We assessed the association between self-reported victimization and offending through a correlation. E-Risk data confirmed the association between victimization and offending. Adolescents who were victimized were significantly more likely to offend ( $r=0.42,95 \%$ CI $0.39-0.46)$.

\section{Do Both Genes and Environment Contribute to the Victim-Offender Overlap?}

The first part of our main analysis was a behavioral genetic analysis to test the hypothesis that both genetic and environmental factors contribute to the victimoffender overlap. It was important to begin with a behavioral genetic model because (a) past research exploring environmental risk factors has produced few conclusive results explaining the victim-offender overlap and (b) past research using behavioral genetic models has found that environmental factors do not explain the victim-offender overlap [6, 118]. We used the classical twin study method to decompose variation in victimization, offending, and their overlap into three latent factors: additive genes, the "shared" environment, and the "unique" environment. ${ }^{3}$ The shared environment represents environmental non-genetic factors that make family members similar, whereas the unique environment represents factors that make family members different (and also includes measurement error in the outcome measure). The proportion of variance in a phenotype attributed to the three latent factors is estimated by comparing the degree of similarity between identical (monozygotic (MZ)) twins, who share $100 \%$ of their genetic variation, to the degree of similarity between fraternal (dizygotic (DZ)) twins, who share $50 \%$ of their genetic variation, on average. One key assumption of the twin study method is that monozygotic and dizygotic twin pairs experience trait-relevant environmental exposure equally (the equal environment assumption). ${ }^{4}$ In other words, the zygosity of the twin pair is not tied to environmental experiences; in practice, this biases result towards genetic influence. To estimate the relative importance of the genetic and environmental influences, we compare the correlation of a characteristic between Twin A and Twin B in pairs of MZ twins to that of the correlation of a characteristic between Twin A and Twin B in pairs of DZ twins. If twin correlations are greater for MZ pairs than for DZ pairs, this indicates genetic influences on individual

\footnotetext{
${ }^{3}$ These latent factors are often abbreviated as A (additive genetic effect), $\mathrm{C}$ (shared environmental effect), and $\mathrm{E}$ (unique environmental effect), and the model is often called an ACE model. We avoid using the abbreviated terms in this study as they match the CDC's abbreviation for adverse childhood experiences (ACEs).

${ }^{4}$ For a complete review of twin models, modeling assumptions, and potential sources of bias in the estimated effects, we refer readers to Neale and Maes [81].
} 
differences in a characteristic. If the correlation between twins is equal across $\mathrm{MZ}$ and DZ pairs, this indicates shared environmental influences. If the correlation between $\mathrm{MZ}$ pairs is less than perfect, then we can infer that influences uniquely experienced by each child have made the twins different. We first estimated the twin correlations of victimization, offending, and their overlap. We then fit a bivariate model with Cholesky decomposition, which decomposes the variance of victimization and offending and their covariance into genetic, shared, and non-shared environmental influences. The best fitting model retained additive genetic, shared environmental, and unique environmental influences (model fit statistics can be found in Table S.4).

The correlation between Twin A's victimization and Twin B's victimization was significantly greater for $\mathrm{MZ}$ than for DZ pairs $(0.51,95 \%$ CI $0.44-0.57$, in MZ vs 0.34 , 95\% CI 0.26-0.42, in DZ) (see Table 1). As implied by these correlations, modeling showed that the variation in victimization was explained by genetic factors $(31 \%, 95 \%$ CI 0.12-0.49), shared environmental factors (19\%, 95\% CI 0.03-0.35), and unique environmental factors $(50 \%, 95 \%$ CI $0.44-0.56)$ (see Fig. 1$){ }^{5}$

The correlation between Twin A's offending and Twin B's offending was also significantly greater for $\mathrm{MZ}$ than for DZ pairs $(0.55,95 \%$ CI $0.49-0.60$, in MZ vs $0.39,95 \%$ CI $0.31-0.46$, in DZ). As implied by the correlations, modeling showed that the variation in offending was explained by genetic factors $(33 \%, 95 \%$ CI $0.15-0.51)$, shared environmental factors $(22 \%, 95 \%$ CI $0.06-0.37)$, and unique environmental factors $(45 \%, 95 \%$ CI $0.40-0.51)$.

In contrast, the correlation between Twin A's victimization and Twin B's offending, and vice-versa (also known as the cross-twin, cross-trait correlation), was not significantly different between $\mathrm{MZ}$ and $\mathrm{DZ}$ twins $(0.26,95 \%$ CI $0.18-0.34$, in $\mathrm{MZ}$ vs 0.22 , 95\% CI 0.13-0.31, in DZ; 0.25, 95\% CI 0.17-032, in MZ vs 0.23, 95\% CI 0.15-0.33, in DZ, respectively). This result implied that shared environmental factors were important for explaining the victim-offender overlap.

Given the result that both genes and environment were important for explaining victimization and offending, we next tested the extent to which the genetic and environmental factors influencing each outcome were similar by transforming the results of the Cholesky decomposition into the mathematically identical correlated factors solution (Loehlin 1996). ${ }^{6}$

The correlation $(r)$ between the factors was estimated using the following formula;

$$
r=\frac{(v o)(v)}{\sqrt{\left(v^{2}\right)\left((v o)^{2}+\left(o^{2}\right)\right)}},
$$

where for a given factor (additive genetic, shared environment, unique environment), vo represents the unstandardized variance for victimization-offending, $v$ represents the

\footnotetext{
5 The percentages represent the standardized variances, or the proportion of variation explained by each given factor as calculated by $V_{x}^{*}=V_{x} / V_{p}$, where $V_{p}$ is the sum of all the unstandardized variance components and $V_{x}$ is the unstandardized variance of a given factor.

${ }^{6}$ The correlations were calculated using unstandardized forms of the variance components found in Table 1. The unstandardized variance components, standardized variance components, and the formulae for calculating the correlations between the factors can be found in Table S.5.
} 
Table 1 Estimated correlations between victimization and offending at age 18 years within and between twin pairs, by zygosity, $95 \%$ confidence interval in parentheses

Monozygotic

\section{Victimization Twin A \\ Offending Twin A}

Dizygotic

$$
\begin{aligned}
& \text { Victimization Twin A } \\
& \text { Offending Twin A }
\end{aligned}
$$

$$
\begin{aligned}
& 0.51(0.44-0.57) \\
& 0.26(0.18-0.34)
\end{aligned}
$$

$0.34(0.26-0.42)$

$0.22(0.13-0.31)$
$0.39(0.31-0.46)$

The correlation between victimization and offending in the full cohort was 0.42 . The correlation among monozygotic twins $(0.42$; 95\%CI $0.35-0.48)$ and dizygotic twins $(0.44$; 95\%CI $0.35-0.51)$ was not significantly different from the full cohort. The cross-twin cross-trait correlations were constrained to offending Twin A victimization Twin $\mathrm{B}$ in the bivariate Cholesky decomposition twin model

unstandardized variance for victimization, and $o$ represents the unstandardized variance for offending.

Figure 1 shows that the genetic factors between victimization and offending were correlated at $0.28(95 \% \mathrm{CI} 0-0.63)$, indicating that victimization and offending had relatively little genetic influence in common. However, the shared environmental factors that accounted for the overlap between victimization and offending were correlated at 0.86 (95\% CI 0.36-1.00), indicating that victimization and offending were influenced by many of the same shared environmental risk factors. The unique environmental factors between victimization and offending were correlated at 0.33 (95\% CI $0.26-0.40)$, indicating that victimization and offending were influenced by some of the same unique environmental risk factors. Through path tracing, we calculated that the proportion of the covariance between

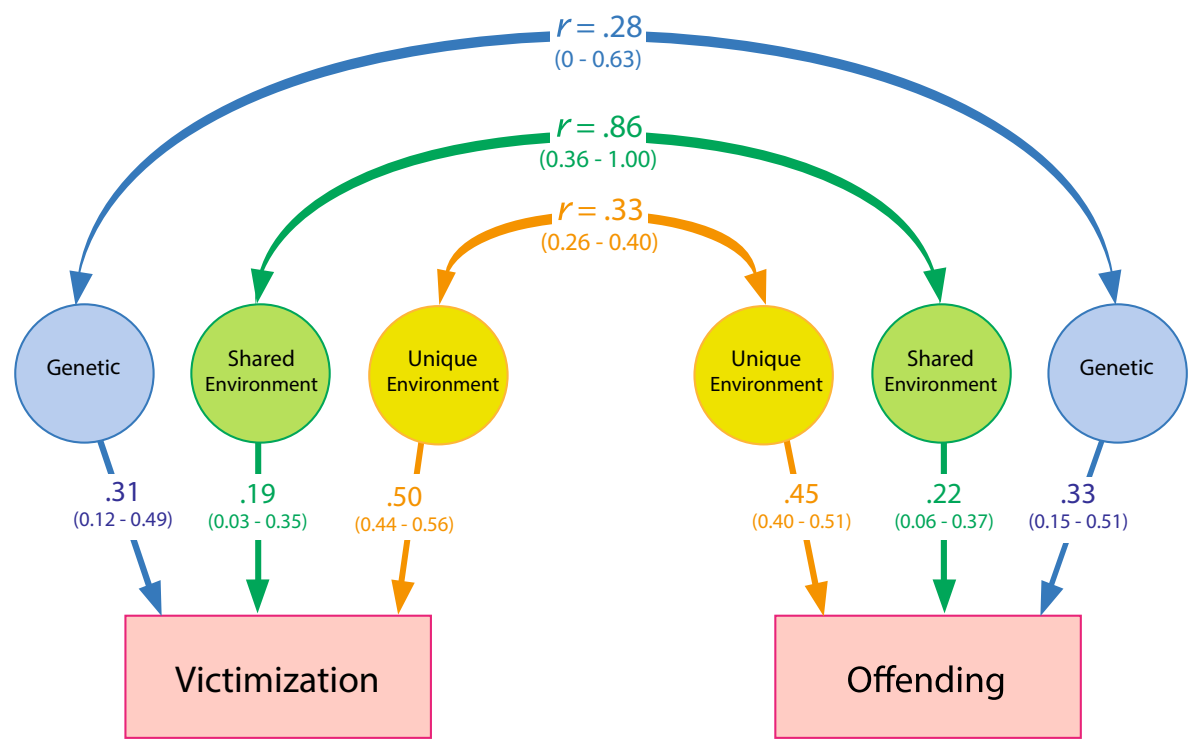

Fig. 1 Correlated factor solution from the bivariate twin model. Univariate estimates showed that victimization and offending were influenced by genetic and environmental factors. Correlations showed that victimization and offending were affected by many of the same shared environmental factors 
victimization and offending that was explained by genetic factors was $22 \%$ (95\% CI 0 0.56 ), by shared environmental factors $40 \%$ (95\% CI $0.10-0.68$ ) and by unique environmental factors $37 \%$ (95\% CI $0.28-0.48)$. In sum, our results show that in this cohort, victimization and offending were under genetic and environmental influence. A large part of the overlap in victimization and offending could be attributed to many of the same (unmeasured) environmental factors.

We analyzed sex heterogeneity in the victim-offender overlap and found that, while there were some minor sex differences, the results between males and females were substantively similar. With about 500 pairs of boys and 500 pairs of girls, our cohort was not large enough to yield decisive tests of sex differences [102]. Sex-specific correlations followed the same pattern and can be found in Table S.6.

\section{Using a Variable-Ventered Approach, Do Childhood Personal Risk Factors and Adverse Childhood Experiences Positively Contribute to the Victim-Offender Overlap?}

The second part of our analysis used a variable-centered approach to test the hypotheses that early childhood personal risk factors and the accumulation of adverse childhood experiences positively contribute to the victim-offender overlap. As in previous research, we found that the same risk factors that were associated with victimization were also generally associated with offending (see Table 2). Next, we tested the extent to which these risk factors accounted for the zero-order correlation between victimization and offending (which was $r=0.42,95 \%$ CI 0.39-0.46). In this approach, we examined partial correlations between victimization and offending while controlling for each risk factor separately. We then calculated the amount of reduction in the correlation between victimization and offending, after partialling out common risk factors (see final column of Table 2). A reduced correlation would imply that the risk factor helps explain the victim-offender overlap.

Table 2 shows that the risk factors, both personal risks and adverse childhood experiences, produced relatively weak reductions in the victimization-offending zero-order correlation. The strongest reductions came from the personal risk factors of low self-control and childhood self-reported delinquency, each of which reduced the zero-order correlation by $13 \%$. The cumulative scale of all ACEs reduced the zero-order correlation by $11 \%$. The summary scale of all personal risk factors combined with ACEs reduced the zero-order correlation by $12 \%$, suggesting that personal risk factors and ACEs confer overlapping risk to the victim-offender overlap. As anticipated, when taken one-by-one, the single adversities contained in the ACEs scale produced weak reductions in the correlation between victimization and offending. The remaining variables (personal risk factors and the individual ACEs) all reduced the zero-order correlation between victimization and offending by less than $10 \%$ each.

\section{Using a Person-Centered Approach, Do Childhood Personal Risk Factors and Adverse Childhood Experiences Positively Contribute to the Victim-Offender Overlap?}

In a complementary, person-centered approach, we categorized individuals into four groups: neither victims nor offenders (individuals scoring 0 on both variety score 
Table 2 Association between risk factors, victimization $(v)$ and offending $(o)$ in a birth cohort. The table shows correlations between each risk factor with victimization and offending, respectively, and the partial correlation between victimization and offending, after partialling out effect of each risk factor

\begin{tabular}{|c|c|c|c|c|}
\hline \multirow[t]{2}{*}{ Risk factor } & \multicolumn{2}{|c|}{ Correlation $(r)$} & \multicolumn{2}{|c|}{ Partial correlation } \\
\hline & $v$ & $o$ & $v-o(r)$ & $\begin{array}{l}\text { Reduces } v \text { - } o \text { zero-order } \\
\text { correlation by }(\%)^{\mathrm{a}}\end{array}$ \\
\hline \multicolumn{5}{|l|}{ Personal risk factors } \\
\hline Low self-control $z$-score & 0.266 & 0.345 & 0.365 & 13.6 \\
\hline Cognitive ability & -0.088 & -0.102 & 0.419 & 0.7 \\
\hline Early puberty & 0.072 & $0.019^{\mathrm{ns}}$ & 0.416 & 1.4 \\
\hline Conduct disorder diagnosis & 0.208 & 0.320 & 0.384 & 9.1 \\
\hline Childhood self-reported delinquency & 0.235 & 0.441 & 0.366 & 13.3 \\
\hline Childhood substance use & 0.192 & 0.332 & 0.388 & 8.0 \\
\hline Total count of all 19 ACEs & 0.274 & 0.257 & 0.378 & 10.4 \\
\hline Conventional ACEs (up to 9 ACEs) ${ }^{\text {b }}$ & 0.228 & 0.199 & 0.394 & 6.5 \\
\hline Physical abuse & 0.187 & 0.140 & 0.407 & 3.6 \\
\hline Sexual abuse & 0.052 & 0.061 & 0.420 & 0.4 \\
\hline Emotional abuse or neglect & 0.143 & 0.089 & 0.415 & 1.6 \\
\hline Physical neglect & 0.090 & 0.062 & 0.419 & 0.7 \\
\hline Domestic violence exposure & 0.124 & 0.132 & 0.412 & 2.3 \\
\hline Parental antisocial behavior & 0.161 & 0.151 & 0.405 & 3.9 \\
\hline Family history of substance abuse & 0.148 & 0.104 & 0.416 & 1.4 \\
\hline Family history of mental health disorders & 0.108 & 0.072 & 0.411 & 2.6 \\
\hline Parental separation or divorce & 0.130 & 0.136 & 0.413 & 2.2 \\
\hline Expanded ACEs (up to 10 ACEs) & 0.226 & 0.227 & 0.390 & 7.4 \\
\hline Bullying victim & 0.147 & $0.023^{\mathrm{ns}}$ & 0.423 & -0.2 \\
\hline Lived in foster care & 0.089 & 0.068 & 0.418 & 0.8 \\
\hline Low socioeconomic status & 0.116 & 0.107 & 0.415 & 1.7 \\
\hline Peer substance abuse & 0.168 & 0.242 & 0.400 & 5.2 \\
\hline Low parental monitoring (mother) & 0.093 & 0.135 & 0.417 & 1.2 \\
\hline Low parental monitoring (participant) & 0.107 & 0.213 & 0.412 & 2.4 \\
\hline Participant-perceived unsafe neighborhood & 0.165 & $0.036^{\mathrm{ns}}$ & 0.424 & -0.6 \\
\hline High neighbor victimization & 0.073 & 0.053 & 0.425 & -0.7 \\
\hline Neighborhood rated unsafe & 0.089 & 0.112 & 0.415 & 1.6 \\
\hline High-crime neighborhood & 0.053 & $0.026^{\mathrm{ns}}$ & 0.416 & 1.3 \\
\hline Summary scale of all risk factors ${ }^{\mathrm{c}}$ & 0.232 & 0.361 & 0.372 & 11.7 \\
\hline
\end{tabular}

Pairwise correlations for full sample

${ }^{a}$ Percent difference between zero-order correlation (0.42) and partial correlation

${ }^{\mathrm{b}}$ Our measure includes 9 items, in contrast to the 10 conventional ACEs, because we found that coders could not empirically separate emotional abuse and emotional neglect in a reliable way

${ }^{\mathrm{c}}$ The summary scale of all risk factors added conventional ACEs, expanded ACEs, and personal risk factors. Study members were counted as having the personal risk factor if they were in the top quartile of low selfcontrol, early puberty, childhood self-reported delinquency, and childhood substance use; in the bottom quartile of cognitive ability; met the diagnostic criteria for conduct disorder

${ }^{\mathrm{ns}} p>.05$. All other correlations significant $p<.05$, significance adjusted for within-family clustering 
Table 3 Are victim-offenders unique? Comparing victim-offenders to three groups (individuals who are neither victims nor offenders, victims-only, and offenders-only)

\begin{tabular}{|c|c|c|c|c|c|}
\hline & \multicolumn{4}{|c|}{ Victim-offender status } & \multirow{2}{*}{$\begin{array}{l}p<.05 \text { co } \\
\text { to victim- } \\
\text { offender }^{\mathrm{a}}\end{array}$} \\
\hline & $\begin{array}{l}\text { Neither }(\mathrm{N}) \\
n=659\end{array}$ & $\begin{array}{l}\text { Victim- } \\
\text { only (V) } \\
n=312\end{array}$ & $\begin{array}{l}\text { Offender- } \\
\text { only }(\mathrm{O}) \\
n=380\end{array}$ & $\begin{array}{l}\text { Victim- } \\
\text { offender } \\
n=546\end{array}$ & \\
\hline \multicolumn{6}{|l|}{ Victimization and offending } \\
\hline $\begin{array}{l}\text { Victimization, mean } \\
\text { (SD) }\end{array}$ & $0.00(0.00)$ & $2.39(2.09)$ & $0.00(0.00)$ & $3.85(2.91)$ & $\mathrm{N}, \mathrm{V}, \mathrm{O}$ \\
\hline Offending, mean (SD) & $0.00(0.00)$ & $0.00(0.00)$ & $2.64(2.36)$ & $4.07(3.03)$ & $\mathrm{N}, \mathrm{V}, \mathrm{O}$ \\
\hline \multicolumn{6}{|l|}{ Personal risk factors } \\
\hline $\begin{array}{l}\text { Low self-control z- } \\
\text {-score, mean (SD) }\end{array}$ & $-0.37(0.88)$ & $-0.10(0.89)$ & $0.05(0.99)$ & $0.36(1.02)$ & $\mathrm{N}, \mathrm{V}, \mathrm{O}$ \\
\hline $\begin{array}{l}\text { Cognitive ability, } \\
\text { mean (SD) }\end{array}$ & $99.9(15.4)$ & $98.4(14.8)$ & $100.2(15.6)$ & $98.1(15.5)$ & - \\
\hline $\begin{array}{l}\text { Early puberty, mean } \\
\text { (SD) }\end{array}$ & $2.60(1.08)$ & $2.73(1.13)$ & $2.59(1.11)$ & $2.70(1.12)$ & - \\
\hline $\begin{array}{l}\text { Conduct disorder } \\
\text { diagnosis, } N(\%)\end{array}$ & $35(5.3 \%)$ & $35(11.2 \%)$ & $65(17.1 \%)$ & $151(27.7 \%)$ & $\mathrm{N}, \mathrm{V}, \mathrm{O}$ \\
\hline $\begin{array}{l}\text { Childhood } \\
\text { self-reported } \\
\text { delinquency, mean } \\
\text { (SD) }\end{array}$ & $1.14(1.39)$ & $1.46(1.52)$ & $2.24(2.25)$ & $2.84(2.11)$ & $\mathrm{N}, \mathrm{V}, \mathrm{O}$ \\
\hline $\begin{array}{l}\text { Childhood substance } \\
\text { use, mean (SD) }\end{array}$ & $0.54(0.89)$ & $0.70(0.98)$ & $0.88(1.13)$ & $1.30(1.43)$ & $\mathrm{N}, \mathrm{V}, \mathrm{O}$ \\
\hline $\begin{array}{l}\text { Total of all ACEs (up to } \\
19 \text { ACEs), mean (SD) }\end{array}$ & $2.30(2.18)$ & $3.31(2.53)$ & $2.97(2.34)$ & $4.15(2.87)$ & $\mathrm{N}, \mathrm{V}, \mathrm{O}$ \\
\hline $\begin{array}{l}\text { Conventional ACEs } \\
\text { (up to } 9 \mathrm{ACEs} \text { ), } \\
\text { mean (SD) }\end{array}$ & $1.09(1.28)$ & $1.66(1.56)$ & $1.34(1.37)$ & $2.00(1.69)$ & $\mathrm{N}, \mathrm{V}, \mathrm{O}$ \\
\hline $\begin{array}{l}\text { Physical abuse, } N \\
\quad(\%)\end{array}$ & $17(2.6 \%)$ & $11(3.5 \%)$ & $11(2.9 \%)$ & $52(9.5 \%)$ & $\mathrm{N}, \mathrm{V}, \mathrm{O}$ \\
\hline $\begin{array}{l}\text { Sexual abuse, } N \\
\quad(\%)\end{array}$ & $2(0.3 \%)$ & $2(0.6 \%)$ & $3(0.8 \%)$ & $9(1.6 \%)$ & - \\
\hline $\begin{array}{l}\text { Emotional abuse or } \\
\text { neglect, } N(\%)\end{array}$ & $6(0.9 \%)$ & $11(3.5 \%)$ & $8(2.1 \%)$ & $24(4.4 \%)$ & $\mathrm{N}$ \\
\hline $\begin{array}{l}\text { Physical neglect, } N \\
\text { (\%) }\end{array}$ & $3(0.5 \%)$ & $7(2.2 \%)$ & $2(0.5 \%)$ & $18(3.3 \%)$ & $\mathrm{N}, \mathrm{O}$ \\
\hline $\begin{array}{r}\text { Domestic violence } \\
\text { exposure, } N(\%)\end{array}$ & $80(12.1 \%)$ & $54(17.3 \%)$ & $60(15.8 \%)$ & $127(23.3 \%)$ & $\mathrm{N}, \mathrm{O}$ \\
\hline $\begin{array}{l}\text { Parental antisocial } \\
\text { behavior, } N(\%)\end{array}$ & $103(15.6 \%)$ & $95(30.4 \%)$ & $85(22.5 \%)$ & $183(33.6 \%)$ & $\mathrm{N}, \mathrm{O}$ \\
\hline $\begin{array}{l}\text { Family history of } \\
\text { substance abuse, } \\
N(\%)\end{array}$ & $94(14.3 \%)$ & $77(24.7 \%)$ & $73(19.2 \%)$ & $163(30.0 \%)$ & $\mathrm{N}, \mathrm{O}$ \\
\hline $\begin{array}{l}\text { Family history of } \\
\text { mental health } \\
\text { disorders, } N(\%)\end{array}$ & $167(25.4 \%)$ & $99(32.0 \%)$ & $96(25.3 \%)$ & $204(38.2 \%)$ & $\mathrm{N}, \mathrm{O}$ \\
\hline $\begin{array}{l}\text { Parental separation } \\
\quad \text { or divorce, } N(\%)\end{array}$ & $245(38.0 \%)$ & $163(52.8 \%)$ & $173(46.0 \%)$ & $310(58.1 \%)$ & $\mathrm{N}, \mathrm{O}$ \\
\hline
\end{tabular}


Table 3 (continued)

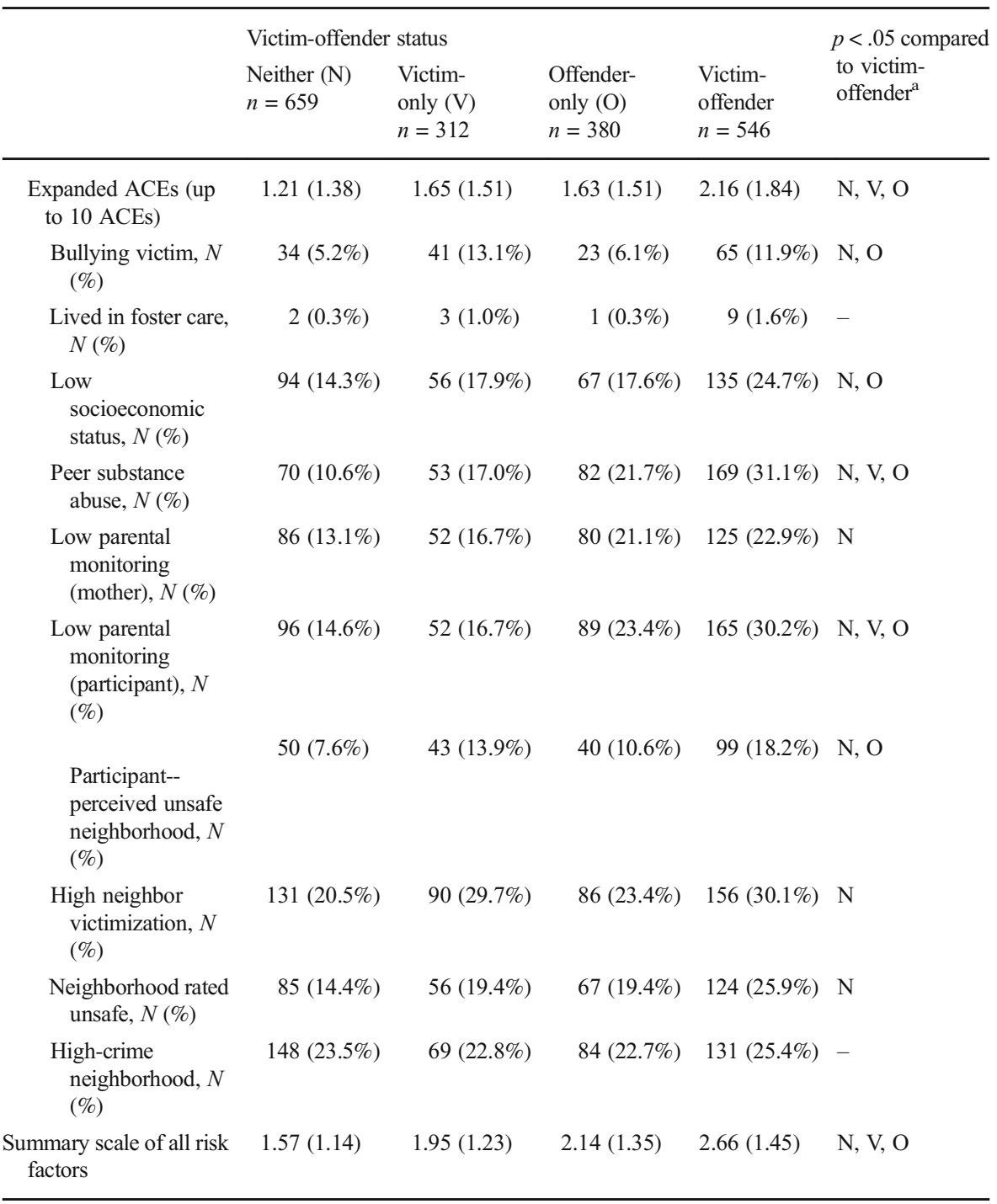

$S D$ standard deviation, $N$ number of Study members

${ }^{a}$ Significant pairwise two-tailed tests between the victim-offender group and each of the other groups are noted by the single letter abbreviation of the group for which the significant difference was found: $\mathrm{N}=$ neither victim nor offender, $\mathrm{V}=$ victim-only, and $\mathrm{O}=$ offender-only. Mean differences tested with Tukey's test. Proportion differences tested with chi-square or Fisher's exact test with $p$ values adjusted for multiple comparisons within rows using the method described by Benjamini and Hochberg (1995)

scales; hereafter "neither", $35 \%$ of the sample), victims-only (individuals scoring 0 on offending variety but $>0$ on victimization variety; 16\%), offenders-only (individuals scoring 0 on victimization variety but $>0$ on offending variety; 20\%), or victimoffenders (individuals scoring greater than 0 on both victimization and offending; $29 \%$ ). We tested whether victim-offenders differed on risk predictors from offenders- 
only, victims-only, or adolescents who were neither. It was not surprising that victimoffenders were consistently worse-off from those adolescents who were neither (Table 3). The interesting question was whether victim-offenders differed from victims-only and offenders-only. In terms of personal risk factors measured in childhood, victim-offenders, compared to all other groups, had lower self-control, were significantly more likely to be diagnosed with conduct disorder, self-reported delinquency and had experimented with substance use. In terms of adverse childhood experiences, victim-offenders, compared to both victims-only and offenders-only, had scored significantly higher on cumulative ACEs. Victim-offenders tended to be worseoff using the individual items from the ACEs scales, but this difference failed to reach statistical significance for many individual ACEs.

Next, we extended the analyses reported in Table 3 by controlling for (a) the variety of victimization and (b) the variety of offending. These controls were important because it is possible that any observed differences between victim-offenders and victims-only and offenders-only could arise simply because victim-offenders are more frequently victimized or are more frequent, high-volume offenders. For each of our eight key risk factors, we used logistic regression to test the likelihood of being a victim-offender versus being (a) a victim-only and (b) an offender-only, controlling for victimization frequency and offending frequency.

Table 4 reports the results of these logistic regression models in odds ratios with 95\% confidence intervals. After controlling for adolescent victimization frequency, the odds that a Study member was identified as a victim-offender compared to a victimonly were still significantly increased by lower self-control $(1.32,95 \%$ CI 1.12-1.55), in the presence of a conduct disorder diagnosis $(2.18,95 \%$ CI 1.41-3.39), when more childhood delinquency was self-reported $(1.45,95 \%$ CI 1.31-1.60), when more childhood substance use was self-reported (1.48, 95\% CI 1.26-1.73), when more ACEs were experienced $(1.08,95 \%$ CI 1.02-1.16), and with higher scores on the summary scale of all risks $(1.35,95 \%$ CI 1.19-1.52). After controlling for adolescent offending frequency, the odds that a Study member was identified as a victim-offender compared to an offender-only were still significantly increased by lower self-control $(1.23,95 \%$ CI 1.07-1.42), in the presence of a conduct disorder diagnosis (1.44, 95\% CI $1.02-$ $2.05)$, when more childhood substance use was self-reported (1.18, 95\% CI 1.04-1.34), when more ACEs were experienced $(1.15,95 \%$ CI 1.09-1.22), and with higher scores on the summary scale of all risks $(1.18,95 \%$ CI 1.06-1.31).

In summary, these models showed that in this cohort the victim-offender overlap could be partly explained through both personal risk factors and cumulative ACEs. We additionally conducted a sensitivity analysis using offending as recorded in the UK Police National Computer. Police records covered the period beginning at age 10 years, overlapping with the period covered by the self-reported victimization measure (details can be found in Table S.7). Consistent with our results using self-reports, low selfcontrol, conduct disorder diagnosis, childhood self-reported delinquency, substance use, the scale of 19 ACEs, and the summary scale of all risk factors were all significantly more likely/higher among victim-offenders compared to victims-only. However, when using official records as the indicator of offending, offenders-only and victim-offenders did not appear significantly different from each other, probably because police-recorded offenders - whether victims or not - are in the upper end of the spectrum of risk. 
Table 4 Association between personal risk factors and ACEs and being a victim-offender versus (a) a victimonly and (b) an offender-only

\begin{tabular}{|c|c|c|c|c|c|c|c|c|}
\hline \multirow[t]{4}{*}{ Risk factor } & \multicolumn{8}{|c|}{ Victim-offender versus } \\
\hline & \multirow{2}{*}{\multicolumn{2}{|c|}{$\begin{array}{l}\text { Victim-only } \\
\text { Model } 1 \\
\text { (covariate: male) }\end{array}$}} & \multicolumn{4}{|c|}{ Offender-only } & & \\
\hline & & & \multicolumn{2}{|c|}{$\begin{array}{l}\text { Model } 2 \\
\text { (covariates: male, } \\
\text { victimization) }\end{array}$} & \multicolumn{2}{|c|}{$\begin{array}{l}\text { Model } 1 \\
\text { (covariate: male) }\end{array}$} & \multicolumn{2}{|c|}{$\begin{array}{l}\text { Model } 2 \\
\text { (covariates: male, } \\
\text { offending) }\end{array}$} \\
\hline & OR & $95 \% \mathrm{CI}$ & OR & $95 \% \mathrm{CI}$ & OR & $95 \% \mathrm{CI}$ & OR & $95 \% \mathrm{CI}$ \\
\hline \multicolumn{9}{|l|}{ Personal risk factors } \\
\hline Low self-control $z$-score & 1.43 & $(1.22-1.69)$ & 1.32 & $(1.12-1.55)$ & 1.21 & $(1.11-1.32)$ & 1.23 & $(1.07-1.42)$ \\
\hline Cognitive ability & 1.00 & $(0.99-1.01)$ & 1.00 & $(0.99-1.01)$ & 0.99 & $(0.99-1.00)$ & 1.00 & $(0.99-1.01)$ \\
\hline Early puberty & 1.02 & $(0.89-1.17)$ & 0.98 & $(0.85-1.13)$ & 1.06 & $(0.98-1.15)$ & 1.08 & $(0.95-1.22)$ \\
\hline Conduct disorder diagnosis & 2.47 & $(1.61-3.77)$ & 2.18 & $(1.41-3.39)$ & 1.45 & $(1.18-1.77)$ & 1.44 & $(1.02-2.05)$ \\
\hline $\begin{array}{l}\text { Childhood self-reported de- } \\
\text { linquency }\end{array}$ & 1.49 & $(1.35-1.65)$ & 1.45 & $(1.31-1.60)$ & 1.08 & $(1.03-1.13)$ & 1.06 & $(0.98-1.14)$ \\
\hline Childhood substance use & 1.53 & $(1.31-1.79)$ & 1.48 & $(1.26-1.73)$ & 1.17 & $(1.08-1.27)$ & 1.18 & $(1.04-1.34)$ \\
\hline $\begin{array}{l}\text { Total of all ACEs (up to } 19 \\
\text { ACEs) }\end{array}$ & 1.12 & $(1.05-1.19)$ & 1.08 & $(1.02-1.16)$ & 1.11 & $(1.07-1.15)$ & 1.15 & $(1.09-1.22)$ \\
\hline $\begin{array}{l}\text { Summary scale of all risk } \\
\text { factors }\end{array}$ & 1.41 & $(1.25-1.59)$ & 1.35 & $(1.19-1.52)$ & 1.17 & $(1.10-1.24)$ & 1.18 & $(1.06-1.31)$ \\
\hline
\end{tabular}

Victim-offender versus victim-only models $n=858$. Victim-offender versus offender-only models $n=926$. Models of model 1 type include the risk factor and male. Models of model 2 type include the risk factor, male, and victimization or offending variety

$O R$ odds ratio, $C I$ confidence interval

\section{Discussion}

Criminal justice policies have historically tended to contrast victims with offenders, but they are often the same people [66]. Our findings provide new evidence that during the peak age-period of crime victimization and offending, many victims are offenders and many offenders are victims. Moreover, victim-offenders seem to be characterized by early-onset antisocial behavior and are exposed to multiple adverse childhood experiences. Our findings make three novel contributions. First, our quantitative twin models showed that the victim-offender overlap is influenced by the environment and that victimization and offending have many environmental risks in common. Recall, prior studies had shown that most of the variation in the victim-offender overlap was due to genetic factors.

Second, in line with past developmental research comparing single risks to an accumulation of risks for other, non-crime, outcomes, our findings showed that childhood risk for the victim-offender overlap is cumulative in nature. Nonoffending or not being victimized was associated with few or no risks. Being both a victim and an offender was associated with the largest accumulation of risks. Being either a pure victim or a pure offender fell in-between and was associated with a modest number of risks. Prior studies of the victim-offender overlap often reported that risk factors had little or no effect on the overlap, but this may have arisen from testing one risk factor at a time. 
Third, we studied risk factors prospectively assessed during childhood, and our results illustrate that a developmental approach is useful for predicting the victimoffender overlap. Victim-offender overlap research can be further advanced through tests of other life course theories (e.g., the age-graded theory of crime) and through the use of longitudinal methods. This focus does not detract from the value and importance of research on the situational determinants of the victim-offender overlap. Many of the factors that we analyzed could easily predispose victims and offenders to switch roles during a single incident, or within a few days or weeks. This research aims to highlight the relevance of a longitudinal view of the overlap and highlight its developmental etiology. Current theories of crime over the life course should be augmented to consider victimization as an outcome predicted by similar risks as offending and an outcome likely to occur simultaneously with offending in the presence of an abundance of risk.

In line with meta-analyses on the heritability of antisocial behavior [102], our twin models supported our first hypothesis that both genes and environmental factors would be important for explaining the victim-offender overlap. Past research, in contrast, found that shared environmental factors had no significant effect on the victim-offender overlap [6, 118]. Sample differences in age could not explain the contrasting results, as the age range in our study was not noticeably different from ages covered by past research. ${ }^{7}$ One possible reason that our findings differed from those of past results is that the E-Risk Study has retained over $90 \%$ of its participants. In contrast, the Add Health Study retained about $75 \%$ of respondents between Waves I and II/III; non-participation and attrition conspire to reduce representation of people living in adverse homes. Additionally, the measure of victimization used in Add Health was limited to a few types of severe violent crime victimization, resulting in quite low prevalence and frequency of victimization-less than $25 \%$ of the sample had been victimized and the mean number of victimizations was less than 1 . In contrast, our measure of victimization captured a wider variety of types of victimization, a few of which were family-based. The prevalence and frequency of victimization in our study are congruent with nationwide estimates of victimization derived from the NSPCC survey [45]. Regardless of particular data-related issues, a past meta-analysis of antisocial behavior [102] implies that many more behavioral genetic studies will be needed before drawing firm conclusions about genetic and environmental effects on the victim-offender overlap. Speaking to the broader controversy of using a twin design $[8,18,77]$, our results showed that twin designs in criminology are valuable for showing environmental effects.

Our person- and variable-centered models partially supported our second hypothesis that personal risk factors would be important for explaining the victim-offender overlap. In the variable-centered approach, low self-control, conduct disorder diagnosis, childhood self-reported delinquency, and childhood substance use each explained a portion $(\approx 8 \%$ or more) of the correlation between victimization and offending. Similarly, in the person-centered approach, Study members who had been diagnosed with conduct disorder, and those with high amounts of low self-control, childhood delinquency, and childhood substance use were significantly more likely to become a

\footnotetext{
${ }^{7}$ A common finding in behavioral genetic research is that genetics explain a greater amount of variance in a characteristic as subjects' age. This, however, is not the case with antisocial behavior. Instead, the influence of both genetic and shared environmental factors tends to decline with age while the influence of unique environmental effects increases [102].
} 
victim-offender versus a victim-only or an offender-only during adolescence. Our results thus supported the prediction from theories of individual heterogeneity that low self-control partly explains the victim-offender overlap. The two other personal risk factors, low cognitive ability and early-onset puberty, were not supported as risks for the victim-offender overlap. To the best of our knowledge, this is the first analysis to test the contribution of these two risk factors to the victim-offender overlap and replication of this novel null finding is needed.

Both our person- and variable-centered models supported our third hypothesis that cumulative adverse childhood experiences (ACEs) would be important for explaining the victim-offender overlap. The results of the variable-centered and person-centered approaches showed that individual ACEs, considered one-by-one, were unhelpful in explaining the victim-offender overlap. In contrast, cumulative ACEs produced relatively stronger reductions in the correlation between victimization and offending, differed significantly between victim-offenders and both victims-only and offendersonly, and significantly increased the odds of being a victim-offender versus an offenderonly. Cumulative risk appeared especially important for neighborhood measures which, when measured individually, had little association with the victim-offender overlap.

\section{Limitations}

There are limitations to our study. First, Study members were asked about their victimization over a six-year period (age 13-18), while they were asked about their offending over a one-year period (age 17-18). For our study, this meant that the overlap may have been based on events a number of years apart. A measure using the same 1year exposure window may have led to fewer Study members reporting victimization and possibly fewer victim-offenders. Although the victim-offender overlap is often measured within a short period of time, many studies on the overlap between victimization and offending consider the offense history of crime victims (as did, for example, Wolfgang's [123] landmark study, which was the first study to empirically establish the victim-offender overlap). In this regard, for our analysis, a longer window of offending may have been more appropriate than restricting the window of victimization. Recall that we were able to capture a multi-year window of offending (from age 10 onwards) with the police-reported offense data (Table S.7), and results were generally consistent with regard to the impact of the risk factors.

Second, we are limited in our ability to make causal inferences. We could not assess the temporal order of victimization and offending, only the overlap. We were, thus, unable to evaluate whether victimization caused offending or vice-versa. Additionally, our research can only support personal risk factors and cumulative adversities as indicators of risk for being a victim-offender and not necessarily as indicators of causation. Yet, randomized controlled experiments of parenting programs have connected lower childhood antisocial behavior and lower childhood maltreatment to lower adolescent delinquency and victimization [34, 84, 89, 124]. Thus, it would seem that reducing childhood antisocial behavior and ACEs could also lower the risk of children becoming adolescent victim-offenders. Moreover, given the nature of ACEs and the behavioral genetic results showing the influence of the shared environment, the family appears to be a good target for intervention. 
Third, given the complexity of the current study, we have not delved further into how childhood risks may predict different types of victimization and offending. However, offense specialization in adolescence is uncommon [90] and many of our Study members were victims of more than one type of crime (see Table S.2). Future research should nonetheless consider the possibility of different childhood risks predicting different types of victimization and offending.

Fourth, the sample was composed of twins, so the results may not generalize to singletons. However, past studies of singletons show results similar to our prevalence of adolescent victimization and offending and childhood conventional ACEs. Additionally, past research has demonstrated the similarity between twins and singletons in antisocial behavior and risk factors for antisocial behavior [7].

\section{Conclusions}

In this study, we have shown that the victim-offender overlap can be at least partly explained by early childhood characteristics and by the accumulation of multiple adverse childhood experiences, factors commonly used to identify "at risk" youth. Our results thus support the developmental axiom that past behavior and experience are predictive of future behavior and experience, and we extend this observation to show that it applies to the victim-offender overlap. Established delinquency-prevention programs have the opportunity to warn their clients about the risks of victimization and, perhaps, educate them on self-protective measures. Our study also showed that existing theories of the victimoffender overlap should be adapted to take a developmental perspective of risk beginning in childhood. Efforts to prevent adolescent victimization and offending may begin with a situational focus, such as programs to prevent retaliatory violence, but could improve their efficacy by recognizing that victimization and offending have their roots in childhood.

Acknowledgements Our thanks to CACI, Google Street View, and the UK Ministry of Justice for assistance with data. We are grateful to the study mothers and fathers, the twins, and the twins' teachers for their participation. We thank David L. Corcoran and Joseph A. Prince for their consult, and Antony Ambler, Andrea Danese, Felix Schroeder, Karen Sugden, and members of the E-Risk team for their help, dedication, hard work, and insights.

Funding information The E-Risk Study is funded by the Medical Research Council (UKMRC grant G1002190). Additional support was provided by US NICHD grant HD077482 and by the Jacobs Foundation and the Avielle Foundation. Amber L. Beckley was supported by a Marie Curie fellowship from the Seventh Framework Programme (FP7) of the European Union.

Open Access This article is distributed under the terms of the Creative Commons Attribution 4.0 International License (http://creativecommons.org/licenses/by/4.0/), which permits unrestricted use, distribution, and reproduction in any medium, provided you give appropriate credit to the original author(s) and the source, provide a link to the Creative Commons license, and indicate if changes were made.

\section{References}

1. Aaltonen, M. (2016). To whom do prior offenders pose a risk? Victim-offender similarity in policereported violent crime. Crime \& Delinquency. https://doi.org/10.1177/0011128716654713.

2. Adverse Childhood Experiences (ACEs). (2017). https://www.cdc.gov/violenceprevention/acestudy/index. html. Accessed 19 July. 
3. Anda, R. F., Felitti, V. J., Douglas Bremner, J., Walker, J. D., Whitfield, C., Perry, B. D., Dube, S. R., \& Giles, W. H. (2006). The enduring effects of abuse and related adverse experiences in childhood: a convergence of evidence from neurobiology and epidemiology. European Archives of Psychiatry and Clinical Neuroscience, 256(3), 174-186. https://doi.org/10.1007/s00406-005-0624-4.

4. Averdijk, M. (2010). Reciprocal effects of victimization and routine activities. Journal of Quantitative Criminology, 27(2), 125-149. https://doi.org/10.1007/s10940-010-9106-6.

5. Ball, H. A., Arseneault, L., Taylor, A., Maughan, B., Caspi, A., \& Moffitt, T. E. (2008). Genetic and environmental influences on victims, bullies and bully-victims in childhood. Journal of Child Psychology and Psychiatry, 49(1), 104-112. https://doi.org/10.1111/j.1469-7610.2007.01821.x.

6. Barnes, J. C., \& Beaver, K. M. (2012). Extending research on the victim-offender overlap evidence from a genetically informative analysis. Journal of Interpersonal Violence, 27(16), 3299-3321. https://doi.org/10.1177/0886260512441259.

7. Barnes, J. C., \& Boutwell, B. B. (2013). A demonstration of the generalizability of twin-based research on antisocial behavior. Behavior Genetics, 43(2), 120-131. https://doi.org/10.1007/s10519-012-9580-8.

8. Barnes, J. C., Wright, J. P., Boutwell, B. B., Schwartz, J. A., Connolly, E. J., Nedelec, J. L., \& Beaver, K. M. (2014). Demonstrating the validity of twin research in criminology. Criminology, 52(4), 588-626. https://doi.org/10.1111/1745-9125.12049.

9. Baron, S. W., \& Hartnagel, T. F. (1998). Street youth and criminal violence. Journal of Research in Crime and Delinquency, 35(2), 166-192.

10. Beaver, K. M., Nedelec, J. L., Barnes, J. C., Boutwell, B. B., \& Boccio, C. (2016). The association between intelligence and personal victimization in adolescence and adulthood. Personality and Individual Differences, 98(August), 355-360. https://doi.org/10.1016/j.paid.2016.04.068.

11. Belsky, D. W., Caspi, A., Arseneault, L., Bleidorn, W., Fonagy, P., Goodman, M., Houts, R., \& Moffitt, T. E. (2012). Etiological features of borderline personality related characteristics in a birth cohort of 12year-old children. Development and Psychopathology, 24(01), 251-265. https://doi.org/10.1017 /S0954579411000812.

12. Berg, M. T., \& Loeber, R. (2011). Examining the neighborhood context of the violent offendingvictimization relationship: a prospective investigation. Journal of Quantitative Criminology, 27(4), 427-451. https://doi.org/10.1007/s10940-011-9129-7.

13. Berg, M. T., Stewart, E. A., Schreck, C. J., \& Simons, R. L. (2012). The victim-offender overlap in context: examining the role of neighborhood street culture. Criminology, 50(2), 359-390. https://doi. org/10.1111/j.1745-9125.2011.00265.x.

14. Berlin, L. J., Cassidy, J., \& Appleyard, K. (2008). The influence of early attachments on other relationships. In J. Cassidy \& P. R. Shaver (Eds.), Handbook of Attachment: Theory, Research, and Clinical Applications (2nd ed., pp. 333-347). New York: Guilford Press.

15. Bjarnason, T., Sigurdardottir, T. J., \& Thorlindsson, T. (1999). Human agency, capable guardians, and structural constraints: a lifestyle approach to the study of violent victimization. Journal of Youth and Adolescence, 28(1), 105-119. https://doi.org/10.1023/A:1021676625844.

16. Boker, S. M., Neale, M. C., Maes, H. H., Spiegel, M., Brick, T. R., Estabrook, R., Bates, T. C., et al. (2016). Open Mx 2.6.9 User Guide.

17. Brezina, T. (1998). Adolescent maltreatment and delinquency: the question of intervening processes. Journal of Research in Crime and Delinquency, 35(1), 71-99. https://doi.org/10.1177/0022427898035001003.

18. Burt, C. H., \& Simons, R. L. (2014). Pulling back the curtain on heritability studies: biosocial criminology in the postgenomic era. Criminology, 52(2), 223-262. https://doi.org/10.1111/17459125.12036.

19. Carlson, V., Cicchetti, D., Barnett, D., \& Braunwald, K. (1989). Disorganized/disoriented attachment relationships in maltreated infants. Developmental Psychology, 25(4), 525-531. https://doi.org/10.1037 /0012-1649.25.4.525.

20. Caspi, A., \& Moffitt, T. E. (1991). Individual differences are accentuated during periods of social change: the sample case of girls at puberty. Journal of Personality and Social Psychology, 61(1), 157-168. https://doi.org/10.1037/0022-3514.61.1.157.

21. Chen, X. (2009). The link between juvenile offending and victimization the influence of risky lifestyles, social bonding, and individual characteristics. Youth Violence and Juvenile Justice, 7(2), 119-135. https://doi.org/10.1177/1541204008328799.

22. Cicchetti, D., \& Lynch, M. (1993). Toward an ecological/transactional model of community violence and child maltreatment: consequences for children's development. Psychiatry, 56(1), 96-118. https://doi.org/10.1080/00332747.1993.11024624.

23. Cohen, L. E., \& Felson, M. (1979). Social change and crime rate trends: a routine activity approach. American Sociological Review, 44(4), 588-608. https://doi.org/10.2307/2094589. 
24. Cohen, L. E., Kluegel, J. R., \& Land, K. C. (1981). Social inequality and predatory criminal victimization: an exposition and test of a formal theory. American Sociological Review, 46(5), 505-524. https://doi.org/10.2307/2094935.

25. Craig, W. M., Pepler, D., \& Connolly, J. (2001). Towards a developmental perspective on victimization. In J. Juvonen \& S. Graham (Eds.), Peer harassment in schools: the plight of the vulnerable and victimized (pp. 242-262). New York: Guilford.

26. Crick, N. R., \& Dodge, K. A. (1996). Social information-processing mechanisms in reactive and proactive aggression. Child Development, 67(3), 993-1002. https://doi.org/10.1111/j.1467-8624.1996. tb01778.x.

27. Crittenden, P. M. (1988). Relationships at risk. In J. Belsky \& T. Nezworski (Eds.), Clinical implications of attachment (pp. 136-176). Hillsdale: Lawrence Erlbaum Associates.

28. Cronholm, P. F., Forke, C. M., Wade, R., Bair-Merritt, M. H., Davis, M., Harkins-Schwarz, M., Pachter, L. M., \& Fein, J. A. (2015). Adverse childhood experiences: expanding the concept of adversity. American Journal of Preventive Medicine, 49(3), 354-361. https://doi.org/10.1016/j. amepre.2015.02.001.

29. Danese, A., \& McEwen, B. S. (2012). Adverse childhood experiences, allostasis, allostatic load, and age-related disease. Physiology \& Behavior, Allostasis and Allostatic Load, 106(1), 29-39. https://doi. org/10.1016/j.physbeh.2011.08.019.

30. DeCamp, W., \& Newby, B. (2015). From bullied to deviant the victim-offender overlap among bullying victims. Youth Violence and Juvenile Justice, 13(1), 3-17. https://doi.org/10.1177/1541204014521250.

31. Denson, T. F., Mehta, P. H., \& Tan, D. H. (2013). Endogenous testosterone and cortisol jointly influence reactive aggression in women. Psychoneuroendocrinology, 38(3), 416-424. https://doi.org/10.1016/j. psyneuen.2012.07.003.

32. Dick, D. M., Rose, R. J., Viken, R. J., \& Kaprio, J. (2000). Pubertal timing and substance use: associations between and within families across late adolescence. Developmental Psychology, 36(2), 180-189. https://doi.org/10.1037/0012-1649.36.2.180.

33. Dodge, K. A., \& Frame, C. L. (1982). Social cognitive biases and deficits in aggressive boys. Child Development, 53(3), 620-635. https://doi.org/10.2307/1129373.

34. Eckenrode, J., Campa, M., Luckey, D. W., Henderson, C. R., Cole, R., Kitzman, H., Anson, E., SidoraArcoleo, K., Powers, J., \& Olds, D. (2010). Long-term effects of prenatal and infancy nurse home visitation on the life course of youths: 19-year follow-up of a randomized trial. Archives of Pediatrics \& Adolescent Medicine, 164(1), 9-15. https://doi.org/10.1001/archpediatrics.2009.240.

35. Evans, G. W., \& Cassells, R. C. (2014). Childhood poverty, cumulative risk exposure, and mental health in emerging adults. Clinical Psychological Science, 2(3), 287-296. https://doi.org/10.1177 12167702613501496.

36. Evans, G. W., Li, D., \& Whipple, S. S. (2013). Cumulative risk and child development. Psychological Bulletin, 139(6), 1342-1396. https://doi.org/10.1037/a0031808.

37. Fagan, J., Piper, E. S., \& Cheng, Y.-T. (1987). Contributions of victimization to delinquency in inner cities. The Journal of Criminal Law and Criminology, 78(3), 586-613. https://doi.org/10.2307 /1143570.

38. Farrington, D. P. (2005). Childhood origins of antisocial behavior. Clinical Psychology \& Psychotherapy, 12(3), 177-190. https://doi.org/10.1002/cpp.448.

39. Feigelman, S., Howard, D. E., Li, X., \& Cross, S. I. (2000). Psychosocial and environmental correlates of violence perpetration among African-American urban youth. Journal of Adolescent Health, 27(3), 202-209. https://doi.org/10.1016/S1054-139X(99)00124-X.

40. Felitti, V. J., Anda, R. F., Nordenberg, D., Williamson, D. F., Spitz, A. M., Edwards, V., Koss, M. P., \& Marks, J. S. (1998). Relationship of childhood abuse and household dysfunction to many of the leading causes of death in adults: the Adverse Childhood Experiences (ACE) Study. American Journal of Preventive Medicine, 14(4), 245-258. https://doi.org/10.1016/S0749-3797(98)00017-8.

41. Felson, R. B., \& Burchfield, K. B. (2004). Alcohol and the risk of physical and sexual assault victimization. Criminology, 42(4), 837-860. https://doi.org/10.1111/j.1745-9125.2004.tb00538.x.

42. Felson, R. B., \& Haynie, D. L. (2002). Pubertal development, social factors, and delinquency among adolescent boys. Criminology, 40(4), 967-988. https://doi.org/10.1111/j.1745-9125.2002.tb00979.x.

43. Finkelhor, D., Hamby, S. L., Ormrod, R., \& Turner, H. (2005). The juvenile victimization questionnaire: reliability, validity, and national norms. Child Abuse \& Neglect, 29(4), 383-412. https://doi.org/10.1016 j.chiabu.2004.11.001.

44. Finkelhor, D., Hamby, S. L., Turner, H. A., \& Ormrod, R. K. (2011). The juvenile victimization questionnaire (JVQ-R2) (2nd Rev.). Durham: Crimes Against Children Research Center. 
45. Fisher, H. L., Caspi, A., Moffitt, T. E., Wertz, J., Gray, R., Newbury, J., Ambler, A., et al. (2015). Measuring adolescents' exposure to victimization: the Environmental Risk (E-Risk) Longitudinal Twin Study. Development and Psychopathology, 27(November), 1399-1416. https://doi.org/10.1017 /S0954579415000838.

46. Glenn, A. L., Raine, A., Schug, R. A., Yu, G., \& Granger, D. A. (2011). Increased testosterone-tocortisol ratio in psychopathy. Journal of Abnormal Psychology, 120(2), 389-399. https://doi. org/10.1037/a0021407.

47. Glueck, S., \& Glueck, E. T. (1950). Unraveling juvenile delinquency. New York: Commonwealth Fund.

48. Gottfredson, M. R. (1981). On the etiology of criminal victimization. Journal of Criminal Law \& Criminology, 72(2), 714-726.

49. Gottfredson, M. R. (1984). Victims of crime: the dimensions of risk. London: Her Majesty's Stationary Office.

50. Gottfredson, M. R., \& Hirschi, T. (1990). A general theory of crime (Vol. xvi). Stanford: Stanford University Press.

51. Graber, J. A., Lewisohn, P. M., Seely, J. R., \& Brooks-Gunn, J. (1997). Is psychopathology associated with the timing of pubertal development? Journal of the American Academy of Child \& Adolescent Psychiatry, 36(12), 1768-1776. https://doi.org/10.1097/00004583-199712000-00026.

52. Hamby, S. L., David, F., Ormrod, D., \& Turner, H. (2004). The comprehensive JV administration and scoring manual. Durham: University of New Hampshire, Crimes Against Children Research Centre.

53. Harden, K. P., \& Mendle, J. (2012). Gene-environment interplay in the association between pubertal timing and delinquency in adolescent girls. Journal of Abnormal Psychology, 121(1), 73-87. https://doi. org/10.1037/a0024160.

54. Hawkins, D. J., Herrenkohl, T., Farrington, D. P., Brewer, D., Catalano, R. F., \& Harachi, T. W. (1998). A review of predictors of youth violence. In R. Loeber \& D. P. Farrington (Eds.), Serious \& violent juvenile offenders: risk factors and successful interventions (pp. 106-146). Thousand Oaks: Sage Publications, Inc.

55. Hawkins, J., Catalano, R. F., \& Miller, J. Y. (1992). Risk and protective factors for alcohol and other drug problems in adolescence and early adulthood: implications for substance abuse prevention. Psychological Bulletin, 112(1), 64-105. https://doi.org/10.1037/0033-2909.112.1.64.

56. Hay, C., \& Evans, M. M. (2006). Violent victimization and involvement in delinquency: examining predictions from general strain theory. Journal of Criminal Justice, 34(3), 261-274. https://doi. org/10.1016/j.jcrimjus.2006.03.005.

57. Haynie, D. L. (2003). Contexts of risk? Explaining the link between girls' pubertal development and their delinquency involvement. Social Forces, 82(1), 355-397. https://doi.org/10.1353/sof.2003.0093.

58. Haynie, D. L., \& Piquero, A. R. (2006). Pubertal development and physical victimization in adolescence. Journal of Research in Crime and Delinquency, 43(1), 3-35. https://doi.org/10.1177 $/ 0022427805280069$.

59. Hindelang, M. J., Gottfredson, M. R., \& Garofalo, J. (1978). Victims of personal crime: an empirical foundation for a theory of personal victimization. Pensacola: Ballinger Pub. Co..

60. Hosser, D., Raddatz, S., \& Windzio, M. (2007). Child maltreatment, revictimization, and violent behavior. Violence and Victims, 22(3), 318-333. https://doi.org/10.1891/088667007780842829.

61. Hsieh, C.-C., \& Pugh, M. D. (1993). Poverty, income inequality, and violent crime: a meta-analysis of recent aggregate data studies. Criminal Justice Review, 18(2), 182-202. https://doi.org/10.1177 /073401689301800203.

62. Jennings, W. G., Park, M., Tomsich, E. A., Gover, A. R., \& Akers, R. L. (2011). Assessing the overlap in dating violence perpetration and victimization among South Korean college students: the influence of social learning and self-control. American Journal of Criminal Justice: AJCJ, 36(2), 188-206. https://doi.org/10.1007/s12103-011-9110-x.

63. Jennings, W. G., Piquero, A. R., \& Reingle, J. M. (2012). On the overlap between victimization and offending: a review of the literature. Aggression and Violent Behavior, 17(1), 16-26. https://doi. org/10.1016/j.avb.2011.09.003.

64. Kim, S. (2015). Ppcor: partial and semi-partial (part) correlation. (version R package version 1.1). https://CRAN.R-project.org/package=ppcor.

65. Kuhl, D. C., Warner, D. F., \& Wilczak, A. (2012). Adolescent violent victimization and precocious union formation. Criminology, 50(4), 1089-1127. https://doi.org/10.1111/j.1745-9125.2012.00288.x.

66. Lauritsen, J. L., and Laub, J. H. (2007). Understanding the link between victimization and offending: new reflections on an old idea. In , M. Hough and M. Maxfield (Eds.), Crime Prevention Studies 22, (pp. 55-75). 
67. Lauritsen, J. L., Laub, J. H., \& Sampson, R. J. (1992). Conventional and delinquent activities: implications for the prevention of violent victimization among adolescents. Violence and Victims, $7(2), 91-108$.

68. Lauritsen, J. L., Davis, K. F., \& Quinet. (1995). Repeat victimization among adolescents and young adults. Journal of Quantitative Criminology, 11(2), 143-166. https://doi.org/10.1007/BF02221121.

69. Lauritsen, J. L., Sampson, R. J., \& Laub, J. H. (1991). The link between offending and victimization among adolescents. Criminology, 29, 265.

70. Loeber, R. (1988). Natural histories of conduct problems, delinquency, and associated substance use. In B. B. Lahey and A. E. Kazdin (Eds.), Advances in clinical child psychology, (pp. 73-124). Advances in clinical child psychology 11. Springer US. doi:https://doi.org/10.1007/978-1-4613-9829-5_2.

71. Loeber, R., \& Hay, D. (1997). Key issues in the development of aggression and violence from childhood to early adulthood. Annual Review of Psychology, 48(1), 371-410. https://doi.org/10.1146 /annurev.psych.48.1.371.

72. Maldonado-Molina, M. M., Jennings, W. G., Tobler, A. L., Piquero, A. R., \& Canino, G. (2010). Assessing the victim-offender overlap among Puerto Rican youth. Journal of Criminal Justice, 38(6), 1191-1201. https://doi.org/10.1016/j.jcrimjus.2010.09.008.

73. Maxfield, M., \& Widom, C. S. (1996). The cycle of violence: revisited 6 years later. Archives of Pediatrics \& Adolescent Medicine, 150(4), 390-395. https://doi.org/10.1001/archpedi.1996.02170290056009.

74. McIntyre, J. K., \& Widom, C. S. (2010). Childhood victimization and crime victimization. Journal of Interpersonal Violence. https://doi.org/10.1177/0886260510365868.

75. Moffitt, T. E. (1993). Adolescence-limited and life-course-persistent antisocial behavior: a developmental taxonomy. Psychological Review, 100(4), 674-701. https://doi.org/10.1037/0033-295X.100.4.674.

76. Moffitt, T. E., Arseneault, L., Belsky, D., Dickson, N., Hancox, R. J., Harrington, H. L., Houts, R., et al. (2011). A gradient of childhood self-control predicts health, wealth, and public safety. Proceedings of the National Academy of Sciences, 108(7), 2693-2698. https://doi.org/10.1073/pnas.1010076108.

77. Moffitt, T. E., \& Beckley, A. (2015). Abandon twin research? Embrace epigenetic research? Premature advice for criminologists. Criminology, 53(1), 121-126. https://doi.org/10.1111/1745-9125.12061.

78. Moffitt, T. E., \& E-Risk Study Team. (2002). Teen-aged mothers in contemporary Britain. Journal of Child Psychology and Psychiatry, and Allied Disciplines, 43(6), 727-742.

79. Montoya, E. R., Terburg, D., Bos, P. A., \& van Honk, J. (2011). Testosterone, cortisol, and serotonin as key regulators of social aggression: a review and theoretical perspective. Motivation and Emotion, 36(1), 65-73. https://doi.org/10.1007/s11031-011-9264-3.

80. Neale, M. C., Hunter, M. D., Pritikin, J. N., Zahery, M., Brick, T. R., Kirkpatrick, R. M., Estabrook, R., Bates, T. C., Maes, H. H., \& Boker, S. M. (2016). OpenMx 2.0: extended structural equation and statistical modeling. Psychometrika, 81(2), 535-549. https://doi.org/10.1007/s11336-014-9435-8.

81. Neale, M. C., \& Maes, H. H. (2004). Methodology for genetic studies of twins and families. Dodrecht: Kluwer Academic.

82. Odgers, C. L., Caspi, A., Bates, C. J., Sampson, R. J., \& Moffitt, T. E. (2012). Systematic social observation of children's neighborhoods using Google Street View: a reliable and cost-effective method. Journal of Child Psychology and Psychiatry, 53(10), 1009-1017. https://doi.org/10.1111/j.14697610.2012.02565.x.

83. Okbay, A., Beauchamp, J. P., Fontana, M. A., Lee, J. J., Pers, T. H., Rietveld, C. A., Turley, P., et al. (2016). Genome-wide association study identifies 74 loci associated with educational attainment. Nature, 533(7604), 539-542. https://doi.org/10.1038/nature17671.

84. Olds, D., Henderson, C. R., Cole, R., Eckenrode, J., Kitzman, H., Luckey, D., Pettitt, L., Sidora, K., Morris, P., \& Powers, J. (1998). Long-term effects of nurse home visitation on children's criminal and antisocial behavior: 15-year follow-up of a randomized controlled trial. JAMA, 280(14), 1238-1244. https://doi.org/10.1001/jama.280.14.1238.

85. Osgood, D. W., \& Anderson, A. L. (2004). Unstructured socializing and rates of delinquency. Criminology, 42(3), 519-549.

86. Osgood, D. W., Wilson, J. K., O’Malley, P. M., Bachman, J. G., \& Johnston, L. D. (1996). Routine activities and individual deviant behavior. American Sociological Review, 61(4), 635-655.

87. Patterson, G. R., \& Stouthamer-Loeber, M. (1984). The correlation of family management practices and delinquency. Child Development, 55(4), 1299-1307. https://doi.org/10.2307/1129999.

88. Petersen, A. C., \& Crockett, L. (1985). Pubertal timing and grade effects on adjustment. Journal of Youth and Adolescence, 14(3), 191-206. https://doi.org/10.1007/BF02090318.

89. Piquero, A. R., Farrington, D. P., Welsh, B. C., Tremblay, R., \& Jennings, W. G. (2009). Effects of early family/parent training programs on antisocial behavior and delinquency. Journal of Experimental Criminology, 5(2), 83-120. https://doi.org/10.1007/s11292-009-9072-x. 
90. Piquero, A. R., Oster, R. P., Mazerolle, P., Brame, R., \& Dean, C. W. (1999). Onset age and offense specialization. Journal of Research in Crime and Delinquency, 36(3), 275-299. https://doi.org/10.1177 /0022427899036003002.

91. Plomin, R., DeFries, J. C., \& Loehlin, J. C. (1977). Genotype-environment interaction and correlation in the analysis of human behavior. Psychological Bulletin, 84(2), 309-322. https://doi.org/10.1037/00332909.84.2.309.

92. Posick, C. (2013). The overlap between offending and victimization among adolescents results from the second international self-report delinquency study. Journal of Contemporary Criminal Justice, 29(1), 106-124. https://doi.org/10.1177/1043986212471250.

93. Posick, C., \& Gould, L. A. (2015). On the general relationship between victimization and offending: examining cultural contingencies. Journal of Criminal Justice, 43(3), 195-204. https://doi.org/10.1016 /j.jcrimjus.2015.04.001.

94. Pratt, T. C., \& Cullen, F. T. (2000). The empirical status of Gottfredson and Hirschi's general theory of crime: a meta-analysis. Criminology, 38(3), 931-964. https://doi.org/10.1111/j.1745-9125.2000. tb00911.x.

95. Pratt, T. C., Turanovic, J. J., Fox, K. A., \& Wright, K. A. (2014). Self-control and victimization: a metaanalysis. Criminology, 52(1), 87-116. https://doi.org/10.1111/1745-9125.12030.

96. Pritikin, J. N., Hunter, M. D., \& Boker, S. M. (2015). Modular open-source software for item factor analysis. Educational and Psychological Measurement, 75(3), 458-474. https://doi.org/10.1177 /0013164414554615.

97. R Core Team. (2016). R: a language and environment for statistical computing. Vienna: R Foundation for Statistical Computing https://www.R-project.org/.

98. Radford, L., Corral, S., Bradley, C., Fisher, H., Bassett, C., Howat, N., and Collishaw, S. (2011). Child abuse and neglect in the UK today. Other. http://www.nspcc.org.uk/childstudy.

99. Radford, L., Corral, S., Bradley, C., \& Fisher, H. L. (2013). The prevalence and impact of child maltreatment and other types of victimization in the UK: findings from a population survey of caregivers, children and young people and young adults. Child Abuse \& Neglect, 37(10), 801-813. https://doi.org/10.1016/j.chiabu.2013.02.004.

100. Raine, A., \& Yang, Y. (2006). Neural foundations to moral reasoning and antisocial behavior. Social Cognitive and Affective Neuroscience, 1(3), 203-213. https://doi.org/10.1093/scan/ns1033.

101. Reingle, J. M., \& Maldonado-Molina, M. M. (2012). Victimization and violent offending an assessment of the victim-offender overlap among native American adolescents and young adults. International Criminal Justice Review, 22(2), 123-138. https://doi.org/10.1177/1057567712443966.

102. Rhee, S. H., \& Waldman, I. D. (2002). Genetic and environmental influences on antisocial behavior: a meta-analysis of twin and adoption studies. Psychological Bulletin, 128(3), 490-529. https://doi. org/10.1037/0033-2909.128.3.490.

103. Richman, W. L., Kiesler, S., Weisband, S., \& Drasgow, F. (1999). A meta-analytic study of social desirability distortion in computer-administered questionnaires, traditional questionnaires, and interviews. Journal of Applied Psychology, 84(5), 754-775. https://doi.org/10.1037/0021-9010.84.5.754.

104. Rivera, B., \& Widom, C. S. (1990). Childhood victimization and violent offending. Violence and Victims, 5(1), 19-35.

105. Sampson, R. J., \& Laub, J. H. (1997). Unraveling the social context of physique and delinquency. In R. Adrian, P. A. Brennan, D. P. Farrington, \& S. A. Mednick (Eds.), Biosocial bases of violence (pp. 175188). New York: Plenum Press.

106. Sampson, R. J., \& Lauritsen, J. L. (1990). Deviant lifestyles, proximity to crime, and the offender-victim link in personal violence. Journal of Research in Crime and Delinquency, 27(2), 110-139. https://doi. org/10.1177/0022427890027002002.

107. Sampson, R. J., and Lauritsen, J. L. (1994). Violent victimization and offending: individual-, situational-, and community-level risk factors. In A. J. Reiss and J. A. Roth (Eds.), Understanding an $d$ preventing violence, Volume 3: Social Influences, (pp. 1-114). National Academies Press.

108. Schreck, C. J. (1999). Criminal victimization and low self-control: an extension and test of a general theory of crime. Justice Quarterly : JQ, 16(3), 633-654.

109. Schreck, C. J., Burek, M. W., Stewart, E. A., \& Mitchell Miller, J. (2007). Distress and violent victimization among young adolescents early puberty and the social interactionist explanation. Journal of Research in Crime and Delinquency, 44(4), 381-405. https://doi.org/10.1177 /0022427807305851.

110. Schreck, C. J., \& Fisher, B. S. (2004). Specifying the influence of family and peers on violent victimization extending routine activities and lifestyles theories. Journal of Interpersonal Violence, 19(9), 1021-1041. https://doi.org/10.1177/0886260504268002. 
111. Schreck, C. J., \& Stewart, E. A. (2011). The victim-offender overlap and its implications for juvenile justice. In D. M. Bishop \& B. C. Feld (Eds.), The Oxford Handbook of Juvenile Crime and Juvenile Justice (pp. 47-70). New York: Oxford University Press.

112. Schwartz, M. D., \& Pitts, V. L. (1995). Exploring a feminist routine activities approach to explaining sexual assault. Justice Quarterly, 12, 9.

113. Smith, C., \& Thornberry, T. P. (1995). The relationship between childhood maltreatment and adolescent involvement in delinquency. Criminology, 33(4), 451-481. https://doi.org/10.1111/j.1745-9125.1995. tb01186.x.

114. Smith, D. J., \& Ecob, R. (2007). An investigation into causal links between victimization and offending in adolescents. The British Journal of Sociology, 58(4), 633-659. https://doi.org/10.1111/j.14684446.2007.00169.x.

115. Stattin, H., \& Magnusson, D. (1990). Pubertal maturation in female development. Vol. viii. Paths through Life (Vol. 2). Hillsdale: Lawrence Erlbaum Associates, Inc..

116. Subirana, I., Sanz, H., \& Vila, J. (2014). Building bivariate tables: the compareGroups package for R. Journal of Statistical Software, 57(12), 1-16. 10.18637/jss.v057.i12.

117. Trouton, A., Spinath, F. M., \& Plomin, R. (2002). Twins early development study (TEDS): a multivariate, longitudinal genetic investigation of language, cognition and behavior problems in childhood. Twin Research and Human Genetics, 5(5), 444 448. https://oi.org/10.1375/twin.5.5.444.

118. Vaske, J., Boisvert, D., \& Wright, J. P. (2012). Genetic and environmental contributions to the relationship between violent victimization and criminal behavior. Journal of Interpersonal Violence, 27(16), 3213-3235. https://doi.org/10.1177/0886260512441254.

119. Widom, C. S. (1989). Child abuse, neglect, and violent criminal behavior. Criminology, 27, 251.

120. Widom, C. S., Czaja, S. J., \& Dutton, M. A. (2008). Childhood victimization and lifetime revictimization. Child Abuse \& Neglect, 32(8), 785-796. https://doi.org/10.1016/j.chiabu.2007.12.006.

121. Wilson, D. M., Killen, J. D., Hayward, C., et al. (1994). Timing and rate of sexual maturation and the onset of cigarette and alcohol use among teenage girls. Archives of Pediatrics \& Adolescent Medicine, 148(8), 789-795. https://doi.org/10.1001/archpedi.1994.02170080019004.

122. Wittebrood, K., \& Nieuwbeerta, P. (1999). Wages of sin? The link between offending, lifestyle and violent victimisation. European Journal on Criminal Policy and Research, 7(1), 63-80.

123. Wolfgang, M. E. (1958). Patterns in criminal homicide. Oxford: Univer. Pennsylvania Press.

124. Zielinski, D. S., Eckenrode, J., \& Olds, D. L. (2009). Nurse home visitation and the prevention of child maltreatment: impact on the timing of official reports. Development and Psychopathology, 21(2), 441453. https://doi.org/10.1017/S0954579409000248. 